\title{
СУЧАСНА УКРАЇНСЬКА ВОСННА ДОКУМЕНТАЛІСТИКА: АВТОР ТА АВТОРСЬКА СТРАТЕГІЯ
}

\author{
Іванова О. А., Червінчук А. О.
}

\section{ВСТУП}

Воєнна проблематика увірвалась у життя українців та України у 2014 p. Вона поступово, глибоко і суттєво змінювала нашу дійсність фізично та соціально, а ще трансформувала наш інформаційний світ і когнітивну реальність.

Війна - феномен, світ, що потребує спеціального, цілеспрямованого прийняття, оцінювання й осмислення, - і для тих, хто ії пережив особисто, i для тих, кого вона змусила змінити свій світогляд. Українці й Україна мають право на оцінювання й осмислення воєнного досвіду, який їм довелось здобути. Жертви війни мають право на правду про її події та ії учасників. А ще всіх чекає попереду етап повернення 3 війни, - постконфліктне майбутнє, яке також потребує прийняття, оцінювання й осмислення. В усі часи ці процеси актуалізувала вербальна творчість - художня література, публіцистика, документалістика, мемуаристика, епістолярне письмо тощо. Способи осмислення сучасного українського досвіду війни в нефікціональних творах - тих, що зорієнтовані на фактичний досвід війни та мають прямий зв'язок з дійсністю, - предмет нашої уваги.

Сучасна українська документалістика про події на Сході України це відповідь на запит сучасного українського суспільства, яке потребує - свідомо чи неусвідомлено - об'ємного, розгорнутого, щирого, точного, правдивого репрезентування нинішнього воєнного досвіду українців і України. Репрезентування, що вміщує висвітлення подій без розриву з контекстом, де вони розгортаються та мають свої причини. Репрезентування, що вміщує демонстрацію персональних історій учасників воєнного конфлікту. Поступово, рік за роком, український інформаційний простір наповнився (i продовжує наповнюватись!) воєнною документалістикою, - кількістю вже більше ста книг ${ }^{1}$. Серед iï авторів - журналісти, письменники, учасники бойових дій, волонтери.

${ }^{1}$ Скоріна Г. Книжкова сотня, або \#книги_про_війну. Життя після ATO. URL: http://life-after-ato.com.ua/post/231. 
Сучасна українська воєнна документалістика спрямована на фіксацію та відображення подієвості війни і характеризується як фокусуванням уваги на фактах, так і демонстрацією свідчень учасників і очевидців подій. I якщо досвід Першої та Другої світових війн - це передусім листи із фронту, щоденники, мемуари, то в нинішніх соціокультурних обставинах документалістика фіксує війну насамперед через використання потенціалу та форматів журналістських жанрів, - інтерв'ю з військовими, репортажів 3 місця подій тощо.

Інтерес документалістики до подій на Сході України не слабшає, бо досвід війни потребує прийняття, оцінювання й осмислення. Натомість способи та форми такої актуалізації розширюються, урізноманітнюються, увирязнюються. З'являється все більше документальних творів про війну в Україні, що характеризуються відмінністю у формах подачі матеріалу, авторських інтенціях, об'єктах висвітлення, способах фокусування уваги тощо. Кожна книга про сучасну воєнну українську дійсність у той чи інших спосіб моделює авторське бачення світу війни та місце людини в цій реальності. Науковий інтерес до такого виду вербальної творчості пояснюється необхідністю дослідження способів моделювання сучасної української історії, у якій наявний воєнний досвід, що дасть можливість 3'ясувати, як сучасники війни на Сході України в особі журналістів, письменників і учасників бойових дій бачать іiї (приймають, оцінюють, осмислюють) та на що урешті-решт орієнтують суспільну увагу, на чому формується широка громадська думка щодо конфлікту на Сході України.

Мета дослідження - сформувати комплексне уявлення щодо способів репрезентації досвіду війни на Сході України в сучасній українській воєнній документалістиці, та, взявши до уваги статус автора твору як некомбатанта, професійного комунікатора-журналіста, та комбатанта, учасника бойових дій, виявити авторську позицію та комунікаційні стратегії, що використовуються для осмислення феномену війни i побудови соціокультурного образу сучасної української воєнної історії.

Реалізація поставленої мети потребує вирішення таких завдань:

- виявити й описати способи репрезентації воєнної історії в сучасній українській воєнній документалістиці;

- визначити авторські стратегії опису й осмислення досвіду війни на Сході України, дослідивши специфіку подачі інформації авторомнекомбатантом і автором-комбатантом;

- сформувати уявлення про моделювання сучасної української історії, у якій присутня війна, що постає в українській воєнній документалістиці. 
Відповідно до визначеної мети та поставлених завдань було застосовано такі методи дослідження: загальнонаукові (описовий, аналізу, синтезу, порівняння), спеціальні (структурний, герменевтичний, наративний, метод контент-аналізу). Матеріалом для ілюстрування виявлених характеристик воєнної документалістики стали збірка за редакцією I. Штогріна «АД 242. Історія мужності, братерства та самопожертви» (2016 р.) та книга Д. Якорнова «То АТО. Дневник добровольца» (2016 р.).

\section{1. Позиція автора: організація воєнної історії}

Людина засвоює та відображає отриманий нею досвід відповідно до свого бачення дійсності, через наявну картину світу, - видимі й невидимі зв'язки явищ, процесів, предметів, подій. Це й визначає іiї баченням дійсності, формує ії версію істини. Найочевидніший приклад цього - автор як категорія твору, що постає як спосіб бачення зображеного світу (М. Бахтін).

Як зауважує М. Бахтін, «автор - носій завершеного цілого героя i твору» ${ }^{2}$; для розуміння статусу автора важлива також думка про позицію автора, який знає і бачить не лише відоме героям, але й те, що перебуває поза їхнім кругозором та принципово не доступне ${ }^{3}$ для них. Н. Сівакова так визначила роль автора в документальній літературі: «Автор дає героям поштовх, імпульс пам'яті, напрям - до інтимного світу душі, завдяки чому демонструється драматизм певної події, особливості ії сприймання; надаючи слово кожному герою, монологи зливаються в хор, водночас кожен окремий голос несе в собі свій сюжет» ${ }^{4}$.

Так, автор моделює реальність, у якій перебувають герої (у воєнній документалістиці - реальність війни), водночас герої обмежені в часопросторі та здатні осмислювати ті події, які відбуваються з ними «тут i зараз», а автор забезпечує систематизацію, акцентування, оцінювання, осмислення цього досвіду й артикулює його. Ми переконані: для адекватного дослідження сучасної воєнної документалістики про події на Сході України принципово важливим є статус автора твору, адже цей статус визначає позицію, вектор і спосіб

\footnotetext{
${ }^{2}$ Бахтин М. Автор и герой в эстетической деятельности. Эстетика словесного творчества. Москва : Искусство, 1986. С. 16.

${ }^{3}$ Там само. С. 16-17.

4 Сивакова Н. Функции автора в повествовательной структуре «новой» документальной литературы. Известия Гомельского государственного университета имени. Ф. Скориныл. 2006. № 1 (34). С. 76-83. URL: http://old.gsu.by/ biglib/GSU/Довузовской\%20подготовки/научные\%20публикации/сивакова\%20н.а/ф ункции\%20автора.pdf.
} 
репрезентації воєнної дійсності: автор - спостерігач за подіями (журналіст, некомбатант) i автор - учасник подій (військовий, комбатант). Так, зокрема, автори-спостерігачі (журналісти) повинні керуватися стандартами та рекомендаціями щодо висвітлення воєнних конфліктів, а тому у своїх матеріалах репрезентувати тільки факти, які підкріплені свідченнями учасників/очевидців. Водночас необхідність дотримуватись правил подачі інформації 3 урахуванням воєнної таємниці важливіша за необхідність дотримуватись журналістських стандартів. Натомість безпідставне порушення стандартів журналістики це не виправдовує, як i необхідність формувати соціальне бачення світу війни. Автори-учасники подій (учасники бойових дій) мають більше творчого простору, адже вони не обмежені у форматах організації воєнної історії певними стандартами подачі інформації та комунікаційними завданнями.

Важливо підкреслити загальну тенденцією сучасної воєнної документалістики про події на Сході України наративізувати воєнну історію через об'єднання в єдине ціле декількох історій, спогадів, вражень про ті самі події.

Наратив - одна 3 давніх, широко застосовуваних і перевірених часом форм систематизації інформації (У. Еко, В. Шмід). Наратив об'єднує розрізнену інформацію у структурну цілісність та визначає інші параметри цілого - утримує системні характеристики, організовує бачення зображуваного. Як пише Д. Мак-Квейл, «функція наративу допомогти зрозуміти розповіді із чийогось досвіду. Це здійснюється переважно двома способами: через пов'язування вчинків і подій у логічний послідовний або причинно-наслідковий ланцюжок, або через введення елементів подій i місць фіксованого i впізнаваного характеру» ${ }^{5}$. Серед функціональних можливостей наративу зазначимо контрстратегію, підтримуючу стратегію, введення нового, стратегію виправдання, стратегію спростування, адже як такий наратив «допомагає віднайти логіку людських мотивів, яка надає системності фрагментарним спостереженням, пояснює каузальність процесів, чи вигаданих, чи реальних, робить світ зрозумілим і наближеним до індивідуума, знайомим, своїм» 6 .

Наратив $є$ найоптимальнішим типом репрезентації історії в тому разі, коли необхідно продемонструвати поступове розгортання конфліктної ситуації як цілісної картини подій: ознайомити аудиторію

${ }^{5}$ Мак-Квейл Д. Новини як наратив. Теорія масової комунікаиії. Львів : Літопис, 2010. С. 342-343.

${ }^{6}$ Іванова О. Наратив як складник бренд-платформи. Діалог: медіастудї. Одеса, 2011. Вип. 13. С. 40. 
3 передумовами конфлікту («що» i «чому»), познайомити з героями, передати важкі спогади. О. Маркова зауважує, що війна може наративізуватися декількома способами, як-от: відсутність розповіді про війну (про війну говорити не має бажання чи не виходить, тому акцент на тому, що важливо для автора та не завдасть шкоди його стану); війна як досвід служби (фронтовий побут, навколишня ситуація, дані про бойові завдання та труднощі); війна як колекція епізодів воєнних дій і випадків із фронтової повсякденності (факти про поранення, смерть противника, свідчення про загибель товаришів по службі, про перебування в полоні); війна як досвід кар'єри чи досягнень (факти про виявлення мужності та відваги в боях як самопрезентація); війна як спосіб розуміння себе й інших (війна як досвід, який допомагає осмислити власне життя) ${ }^{7}$.

П. Рікер у контексті дослідження наративності наголошує, що «розповідати означає пояснювати» ${ }^{8}$, адже у процесі конструювання історії думка наратора відділяється від думок персонажів і постає як позиція, з якої весь обсяг відомостей систематизується. Зокрема - це вдалий спосіб наближення до пережитого досвіду подій, які залишились у минулому, спосіб реконструювання того, що вже пройшло.

Наратив у сучасній українській воєнній документалістиці забезпечує організацію воєнного досвіду у вигляді хронологічно орієнтованого поступового викладу історії війни 3 акцентуванням кульмінаційних моментів, а також репрезентації героїв-учасників подій, що розширює уявлення широкої громадськості про розгортання воєнного конфлікту на Донбасі. Зокрема, характерним $є$ «пошук відповіді на питання «що» і «чому» захищали «кіборги» та які сенси історії Донецького аеропорту має знати громадськість» ${ }^{9}$.

У збірці «АД 242. Історія мужності, братерства і самопожертви», де працює автор - спостерігач за подіями, у єдине ціле об'єднано інтерв'ю з учасниками бойових дій (боїв за Донецький аеропорт), що дало змогу змоделювати об'ємне бачення воєнних подій у серії окремих суджень героїв. Актуальні пережиті воєнні події та воєнний досвід військових

${ }^{7}$ Маркова О. Письма с фронта как документ военной эпохи. ИНТЕР. 2016. № 12. C. 54-67. URL: https://cyberleninka.ru/article/n/pisma-s-fronta-kak-dokument-voennoyepohi/pdf.

${ }_{9}^{8}$ Рикёр П. Время и рассказ. Москва : Университетская книга, 1998. С. 206.

9 Червінчук А. Наративність оповіді матеріалу в українській воєнній документалістиці (на прикладі книги «АД 242. Історія мужності, братерства і самопожертви»). Актуальні проблеми розвитку засобів масової комунікації в сучасній Украӥні : матеріали V Всеукраїнської науково-практичної конференції для студентів та аспірантів, 21 квітня 2017 р. Вінниця, 2017. С. 46-47. 
були систематизовані й організавані в сукупний, водночас дискретний образ війни на Донбасі 3 позицій позазнаходження автора спостерігача за подіями.

Основною стратегією автора - учасника подій (він і є героємрозповідачем) $€$ репрезентація свого воєнного досвіду (радше емоційного, ніж професійного), а тому авторські інтенції зосереджені на осмисленні проблеми людини на війні, демонстрації подій, що стали для оповідача «персональною війною». Він, як той, хто пережив участь у бойових діях, не має змоги відгородитися від того, що стало болючим спогадом і закарбувалося в пам'яті назавжди; те, про що автор волів би забути, він репрезентує у вигляді спогадів-рефлексій про пережиті події. Тому такий спосіб репрезентації подій характеризується сконцентрованістю на внутрішньому світі героя-розповідача, його емоційному стані та переживаннях; зовнішній світ демонструється, щоби підсилити повідомлення розповідача та додати динамічності подіям; зазвичай розповідь характеризується викладом тих відомостей, що вплинули на світогляд героя. Саме тому типовим форматом тут стає щоденник або есей, які найкраще передають стан розповідача та перебіг його думок, проте характеризуються фрагментарністю викладу.

Позиція автора визначає авторську стратегію, що стає способом осмислення світу війни, який описується у книзі. Саме в контексті авторської стратегії варто говорити про оцінювання описуваного досвіду, формування ставлення до подій/інших героїв, а також на цьому рівні закладаються умови і створюються концепти війни (військовий, злочинець, ворог, побратим тощо). Феномен війни складний для розуміння й осмислення, а тому професійні комуніканти, якими є автори-спостерігачі, вдаються до зображення війни в контексті зрозумілих аудиторії категорій - через протиставлення одвічних опозицій «добро»/«зло», «герой»/«зрадник», «ворог»/«друг», «свій»/《чужий». Натомість автори - учасники подій репрезентують передусім суб'єктивну реальність, свій власний емоційно зорієнтований досвід війни, а тому твір досягає свого рівня впливовості завдяки інтуїтивним, а не професійно-комунікаційним діям автора, який керується тим, що відчуває, а не наперед визначеним ефектом впливу. Емоції героя-розповідача накладаються на емоції читача, викликають яскраві переживання аудиторії через комунікаційні наміри автора осмислити і систематизувати власний досвід, відрефлексувати його, щоби справитись із тим, що в душі постало і не відпускає, а не через намір сугестивно впливати на читача.

Репрезентація воєнної історії залежить від авторських інтенцій. Різні за типом авторської позиції твори створюють воєнну історію порізному й орієнтуються на досягнення різних ефектів. Автори - 
спостерігачі подій, беручи інтерв'ю в безпосередніх учасників подій, хоча й позбавлені можливості демонструвати власну позицію, створюють образи героїв (військових, що захищали Донецький аеропорт, «кіборгів»), які займають своє чітке і вагоме місце в загальній історії цієї війни, що полегшує розуміння феномену війни аудиторією завдяки формуванню стійкого асоціативного ланцюга: «кіборги» - 242 дні тримання оборони аеропорту - повернення 3 пекла - захист України. Водночас автори - учасники подій вдаються до рефлексування пережитого досвіду. Для таких творів характерні концентрування уваги на побуті в умовах війни, міжособистісних стосунках військових, емоційно забарвлені міркування над тим, що таке війна, що робити людині, яка спіткала війна в сучасному світі, як прийняти/ігнорувати/пережити/переборювати тощо.

$\mathrm{У}$ такий спосіб війна стає емоційно ближчою для тих, хто не має іiі досвіду, а учасники війни - зрозумілішими людьми. Це не що інше, як передача персонального досвіду, передусім емоційного, налаштування на інтимізацію розповіді про індивідуальне, своє, експлікація стану героя-розповідача в кульмінаційні моменти життя на війні, щоби відобразити ії інакше, - не через бойовий досвід, а емоційно, показати, як впливає війна на особистість $з$ усталеним світоглядом, принципами $\mathrm{i}$ цінностями, як змінюється/руйнується усталена поведінка, сприйняття навколишнього світу, коли в ньому $є$ війна. Важливо, що автор учасник подій не намагається нав'язати/сформувати жорсткі уявлення про війну, а надає аудиторії свободу щодо пошуку смислів і значень подій/героїв, які увійшли до створеної ним воєнної історії: читачі мають можливість максимально наблизитися до учасника війни, простежити, відчути, ніби занурившись в авторську свідомість, що відчував, про що думав герой-розповідач у конкретні миттєвості війни, якою вона далась йому.

Для обох типів репрезентації подій характерний поступовий, лінійний виклад історії у вигляді наративу, завдяки якому реалізується формування або дискретного у своїй основі, але укомплектованого, зв'язаного, узгодженого за способом подачі образу реальної сучасної війни (сукупність інтерв’ю у збірці «АД 242. Історія мужності, братерства і самопожертви»), або подієво наповненого, але також дискретного по суті й укомплектованого, узгодженого за способом подачі подієвості воєнного життя («То АТО. Щоденник добровольця»). «Контекст збірки як цілого забезпечуе простір для формувань додаткових сенсів» ${ }^{10}$, а тому виклад матеріалу сконцентровано навколо

\footnotetext{
${ }^{10}$ Іванова О. Сад літератури в журнальній оптиці сучасності : Медіакомунікації з, для і про літературу : монографія. Одеса, 2009. С. 326.
} 
персональних історій, що перетворилися завдяки їхній поєднаності контекстом збірки в колективну історію; сукупність фактів допомагає пояснити специфіку розгортання воєнного конфлікту на Сході України, а акцентування уваги на подіях водночас формує бачення і їхньої причинно-наслідкової пов'язаності. Випуклий, барвистий, наповнений різноманітними унікальними рисами образ війни на Донбасі формується поступово і залишається дискретним, адже він поєднує в ціле окремі думки учасників боїв за Донецький аеропорт, щоденникові записи учасників бойовий операцій, які взаємодоповнюють одна одну, стають окремими репліками в єдиному дискурсі, окремими штрихами в єдиному полотні, окремими миттєвостями війни.

\section{2. Репрезентація воснної дійсності ззовні:}

\section{поведінка автора-спостерігача}

Автор - спостерігач за подіями - це професійний комунікант, який розуміється на масовокомунікаційних процесах, представляє реальність війни, фіксуючи та передаючи свідчення очевидців/учасників подій.

Збірка «АД 242. Історія братерства, мужності і самопожертви» - це історія про бої в Донецькому аеропорту, яка поєднала у собі окремі свідчення учасників цих бойових подій. Низка інтерв’ю в контексті збірки постає як єдине ціле.

Для цієї книги характерним $є$ деталізоване зображення процесу розгортання конфлікту в Донецькому аеропорту, метою якого $\epsilon$ прагнення надати вичерпні, хронологічно зорієнтовані, відповіді на питання: «хто» i «за що» воював у Донецькому аеропорту. Ця авторська інтенція породжена переконанням у запиті суспільства на правду про те, що відбулося в Донецькому аеропорту. Події у збірці систематизовано в окремі підрозділи («квітень - серпень», «вересень листопад», «грудень - січень»), що дає змогу поступального, у контексті перебігу подій, занурення читачів у воєнну хронологію та спонукає до особистого відчуття кульмінаційних етапів розгортання конфлікту. Збірка, яка характеризується принциповою дискретністю в подачі інформації, а тому 3 необхідністю вміщує «пусті» місця, укладена так, щоби в читачів не виникало очевидної потреби заповнювати місця недоокреслення, на власний розсуд тлумачити незрозумілі фрагменти, спеціально шукати додаткові сенси викладеного матеріалу, що пояснюється професійним підходом автора до побудови наративу й інтерв'ювання своїх героїв.

Особливістю збірки є подача окремих історій героїв як цілісного матеріалу: кожна наступна історія характеризується завершеністю та доповнює попередні. Прикметним $є$ те, журналісти, які спілкувалися 3 військовими, виконували роль модераторів, що спрямовували перебіг 
бесіди для максимального розкриття проблеми; основну роль розповідачів взяли на себе безпосередні учасники воєнного конфлікту, які пережили запеклі бої та закарбували у власній пам'яті той досвід. Значна увага у збірці приділена переживанням та відчуттям інтерв'юйованих, проте емоційний складник не переважає над фактами, які стали основним джерелом формування змісту і смислу твору.

Провідна авторська інтенція збірки «АД 242. Історія мужності, братерства та самопожертви» - відображення подієвості, хроніка подій, адже військові передали власні спогади про оборону Донецького аеропорту, виклавши детальні факти: «Першим нашим завданням було виїхати на околицю Пісок у напрямку аеропорту і доставити туди підкріплення, зброю, боєприпаси ${ }^{11}$; «Із 13 січня ворог почав нас активно штурмувати із застосуваннями бронетехніки. В Україну в'їхав гуманітарний конвой, тож з РПГ нас обстрілюваи кожні 7 хвилин. Уранці 15 січня був напад на «Дракон» - пост у пасажирській залі» ${ }^{12}$.

Важливо також підкреслити, що історія оборони Донецького аеропорту вибудована так, щоби розкрити мотиви героїв щодо участі в цих бойових діях, показати, як змінилося їхне життя після участі в боях за аеропорт, зрозуміти, що найстрашніше на війні для військовослужбовців. Автор чітко проблематизує тему людини на війні та того, що вона залишає в людині: «Війна змінює людину, загострює в ній головне. Я впевнений, що з тими людьми, які утримували аеропорт, можна $\mathrm{i}$ в саме пекло йти - вони ніколи не зрадять» ${ }^{13}$. Продемонстровано, що герої оборони аеропору мали різну мотивацію, щоби брати участь у подіях, йшли без воєнного досвіду, щоби реалізувати своє бажання захистити країну від ворогів та не допустити розростання зони бойових дій надалі: «Я от на війну пішов, бо вбили мого побратима, дуже близьку людину» ${ }^{14}$.

Для збірки характерне збереження традиційних підходів до відображення феномену війни, що виражається у формуванні образів війни/військового/ворога як концептів, завдяки яким будується розповідь і описуються враження від подій. Зауважимо, що події на Сході України автори збірки та іiі герої розглядають як війну, розуміючи масштаби цих дій та враховуючи наслідки/жертви. За допомогою спогадів про бої за аеропорт відображена вся трагічність ситуації, у якій раптово опинилась Україна. Українці ще не вповні усвідомлюють масштаб події, що трапилась, а побудова історії війни,

11 АД 242. Історія мужності, братерства та самопожертви / за ред. I. Штогрін. Харків : Клуб сімейного дозвілля, 2016. С. 72.

${ }^{12}$ Там само. С. 173.

13 Там само. C. 27.

14 Там само. С. 55. 
сконструйованої як серія спогадів учасників боїв за аеропорт, наочно демонструє, що війна - це трагедія, жертви, втрати, страждання. Герої збірки відверто називають події на Сході України «війною» (а не антитерористичною операцією/конфліктом), критикують некоректність дій військового командування (на їхню думку, можна було уникнути багатьох жертв та не поступитися ворогові) та виражають своє негативне ставлення до визначення «кіборги», яке нав'язується суспільству для бачення героїв-захисників через віртуалізацію війни в масмедіа.

Характерні для збірки, як і для більшості взірців воєнної документалістики, наявність опозиції «свій»/«чужий» та іiі концептуалізація щодо конкретних соціокультурних обставин війни на Донбасі. «Свій» - той, хто захищає батьківщину, намагається протистояти ворогові, боротися 3 ним - окупантом/агресором; патріот, що намагається захистити національну ідентичність; той, хто не піддається впливу інформаційної війни, пропаганди. «Свої» - це військові, волонтери, мирні жителі. «Чужий» - той, хто намагається захопити/підкорити, знищити батьківщину, зруйнувати ії одвічні цінності, нівелювати єдність країни; той, хто перейшов межу та не виконує важливі соціальні функції. «Чужі» - це сепаратисти/бойовики, місцеве маргіналізоване населення та військові-росіяни (герої збірки наголошують на участі в бойових діях професійних кадрових російських офіцерів).

Важливо, що інтерв'юйовані не намагаються демонструвати свою героїчність, проте неодноразово називають героїчними дії своїх побратимів: «Кожен, хто тримав оборону Донецького аеропорту, герой. Це була робота команди» ${ }^{15}$; «Я, як людина, яку інші називають кіборгом, можу сказати, що насправжніші, наймужніші кіборги - це були хлопці, які сиділи у вежі спостережень» ${ }^{16}$. Ворога у збірці негативізують, зображають, як того, чиї дії неможливо виправдати, 3 ким неможливо налагодити конструктивне спілкування для врегулювання воєнного конфлікту. Цей ворог розуміє лише мову сили, а тому потрібно протистояти йому та боротися 3 ним, позбавляти можливості захоплювати нові українські території та виганяти 3 тих, що він захопив. Ворог у збірці «АД 242. Історія мужності, братерства та самопожертви» постає виразно, у різних ракурсах, проте тут немає намірів висміяти чи принизити його. Ворог постає як такий, що має стратегічне мислення, а тому є рівним суперником у боротьбі («Ворог завжди був попереду нас. Ті завдання, які ставилися, були

15 АД 242. Історія мужності, братерства та самопожертви / за ред. І. Штогрін. Харків : Клуб сімейного дозвілля, 2016. С. 77.

${ }^{16}$ Там само. С. 94. 
несвоєчасними» $\left.{ }^{17}\right)$; він підступний, бо намагається хитрістю здолати українських бійців, виснажити їх («Ворог не давав нам спокою, у нас не було часу навіть поїсти» ${ }^{18}$ ); він також недостойний, дегуманізований, бо знущається над полоненими («Двоє інших хлопців були поранені й потрапили в полон. Одного задушили, а іншого спалили живцем - ось із ким ми воюємо $<\ldots>_{\gg}{ }^{19}$ ).

У збірці «АД 242. Історія мужності, братерства та самопожертви» «Донецький аеропорт» постає не як фізичний простір, зона бойових дій, а смислове поле, зіткане зі штрихів-асоціацій про мужність та витривалість, жертовність військовослужбовців, трагізм подій. Так формується стійкий образ - «Донецький аеропорт», монументальний концепт непохитності, який уособлює пам'ять про запеклі бої впродовж 242 днів, загибель українських військовослужбовцівдобровольців, які стали на захист та давали відсіч ворогові. Цей концепт, згідно з авторською інтенцією збірки, відділяє світ війни, у якому перебувають герої збірки, від мирного світу, де звичайним життям живе країна. Ця межа - фізична і смислова - завадила проникненню світу війни у велику Україну: «Аеропорт став стіною буфером між двома світами» 20 . Збірка репрезентує «Донецький аеропорт» як воєнну операцію, яка увійшла в історію та продовжує бути «живим» болючим спогадом для тих, хто вижив та повернувся із зони бойових дій.

Автор - спостерігач за подіями не обходить своєю увагою емоції героїв, їхні враження від кульмінаційних моментів пережитих подій. У збірці «АД 242. Історія мужності, братерства та самопожертви» продемонстровано, що воєнні події не містять нічого привабливого, а тому подаються без зайвої романтизації. Події в Донецькому аеропорту описуються в атмосфері трагічності ситуації, 3 відчуттям постійної смертельної загрози, подолати яку можна лише вирвавшись із пастки та поборовши ворога. Військовослужбовці відверто висловили своє ставлення до подій, які пережили, i сукупність цих вражень закарбувалася у визначенні «АД»: «Що ми, що сепари називали операцію «Аеропорт» - «АД», тобто пекло у прямому сенсі слова» ${ }^{21}$.

Отже, для організації воєнної історії в сучасній українській воєнній документалістиці з позиції автора - спостерігача за подіями характерне таке: подача матеріалу про війну, зібраного від безпосередніх учасників

17 АД 242. Історія мужності, братерства та самопожертви / за ред. І. Штогрін. Харків : Клуб сімейного дозвілля, 2016. С. 234.

${ }^{18}$ Там само. С. 50.

${ }^{19}$ Там само. С. 75.

${ }^{20}$ Там само. C. 37.

21 Там само. С. 121. 
подій, у вигляді цілісної збірки окремих текстів-інтерв'ю 3 військовими; дотримання ролі модератора бесіди з учасниками подій війни; забезпечення реалізації Я-наративу через використання прямої мови безпосередніх героїв подій; репрезентація концептів семантичного поля «війна» 3 метою створення умов для осмислення феномену війни українським суспільством 3 урахуванням досвіду учасників бойових дій, проте 3 позицій позазнаходження щодо контексту воєнних подій, відсторонено.

\section{3. Репрезентації воснної дійсності зсередини:}

\section{поведінка автора - учасника подій}

У таких творах документалістики демонструється досвід людей, які зіткнулися з війною як безпосередні учасники воєнних подій. Авторучасник подій їх описує, намагається пригадати те, що вже пройшло на війні, прагне експлікувати читачам власне світосприйняття. Усіх таких авторів ріднить «життєвий досвід війни» ${ }^{22}$. Автор - учасник подій - це людина, що має воєнний досвід, досвід бойових дій, адже він виконував певні обов'язки під час воєнних операцій. У процесі воєнного життя він відчув потребу фіксувати свій воєнний досвід, а потім ним поділитися з іншими людьми. У результаті з'являються твори, у яких експлікуються спогади безпосередніх учасників подій, а в епіцентрі уваги автора постають суб'єктивні переживання та погляди на воєнний конфлікт на Сході України.

Зрозуміло, що для майбутнього важливо зафіксувати та зберегти фактичні дані щодо розгортання воєнного конфлікту, проте авториучасники подій воліють концетрувати свою увагу на емоційній складовій частині війни, на саморефлексуванні щодо досвіду війни. Спогади про пережитий досвід стають у таких творах основним чинником формування його змісту і смислу. Комунікаційним наміром автора-учасника подій стає прагнення розповісти свою особисту історію, поділитися 3 аудиторією власними переживаннями, презентувати своє бачення подій, бо війна для них стала персональною. «Людина в армії/на війні» - так можна визначити основну проблематику творів цього сегмента. У них увагу прикуто до внутрішнього «Я» та переживань під час перебування в зоні воєнного конфлікту. Розповідь про війну вибудовується через зображення особистого сприйняття та переживання подій війни, а тому твір демонструє суб’єктивне осмислення феномену війни.

\footnotetext{
${ }^{22}$ Червінчук А. Автор - учасник подій у сучасній українській воєнній документалістиці (на прикладі серії книг «Звіт за серпень'14, «Іловайський щоденник», «Савур-Могила»). Діалог : медіастудіi. 2018. Вип. 24. С. 267.
} 
У збірці «То АТО. Щоденник добровольця» автор - учасник подій Дмитро Якорнов - дотримується стратегії критики й іронізації пережитого досвіду війни. В основу розповіді покладено щоденникові записи автора, що спочатку були опубліковані в мережі Facebook. Подіï війни викладаються у хронологічній послідовності 3 фіксацією координат часу та місця, проте загальна картина характеризується фрагментарністю, преривчастістю. Воєнна історія авторства Д. Якорнова не лише дискретна, вона ще й малоструктурована: розповідач намагався передати свої хаотичні, спонтанні думки й відчуття. У книзі «То АТО. Щоденник добровольця» перед читачами постає історія війни у варіанті щоденникових нотаток. Водночас дописи до мережі Facebook автором не редагувалися, а тому репрезентована авторська позиція щодо подій війни не переосмислювалась після повернення до мирного життя.

Авторська стратегія, реалізована у збірці «То АТО. Щоденник добровольца», така, що розповідь про війну у книзі Д. Якорнова не претендує на фактологічну точність, хоча в ній чітко зазначаються часово-просторові координати, у яких перебуває автор-розповідач. Його комунікаційні наміри - продемонструвати атмосферу армії/війни, суб'єктивні відчуття на війні та солдатське ставлення до подій. Події на Донбасі автор-розповідач описує терміном «АТО», проте не тому, що погоджується 3 ним внутрішньо. «АТО»- це феномен, що у книзі піддається авторській критиці: «АТО - це війна на виснаження: хто швидше розвалиться, Україна або бензоколонка, i, поки ймовірніше найперше, потрібно не дати Україні, Києву та моїй родині стати частиною русского мира» ${ }^{23}$.

Розповідач, що опинився сам на сам із воєнною дійсністю, оцінюючи ситуацію зі своєї позиції солдата, критично визначає перспективи розвитку ситуації: «Мої прогнози завжди були максимально песимістичними - що війна на знищення, на десять років» ${ }^{24}$. Окремої, жорстко критичної, оцінки автора зазнає навчання військових, що згодом опиняться на Донбасі. Здобутий ним досвід навчання в Десні описується іронічно, з явним висміюванням, адже, на думку автора, навчання не принесло користі, не надало необхідних знань і навичок для поведінки в зоні бойових дій: «I головне пробувати писати не тільки про армію! 3 боку виглядає ідіотизмом: війна у країні, ти в армії і в учебці - значить, зобов'язаний вчитися військовому ремеслу або ремонтному, раз в рембате. Останнє відразу відпадає: прикладної навчання тут немає, по жахливим книгам 1967 р.

23 Якорнов Д. То АТО. Дневник добровольца. Харьков : Виват, 2016. С. 9.

${ }^{24}$ там само. С. 16. 
випуску нічого не зрозуміло, а сам по життю рукожоп. Військовому теж не навчають, адже не будеш до розвідників примазуватися!» ${ }^{25}$.

Автор показує воєнну дійсність із власного суб'єктивного погляду військового-«непрофесіонала». Він не має наміру створювати ідеальний чи ідеалізований образ військовослужбовця, який вміло обороняє від ворогів територію рідної країни, навпаки - його погляд максимально далекий від героїзації, він концентрує увагу передусім на недоліках в усьому, із чим стикається в армії та на війні, зокрема розповідає про вживання алкоголю перед виконанням бойових завдань: «Війна тут артилерійська. Бездоганна стрілецька підготовка не потрібна, найпростіших навичок 3 автоматом досить, правда, доводиться доглядати не тільки за своїм, а й за зброєю своїх п'яних колег» ${ }^{26}$.

Негативної оцінки розповідача зазнають i дії військового командування. Насамперед він описує помилки військового керівництва, що призводили до невдач у бойових операціях та втрати позицій: «Ніякої логіки в діях керівництва країни i військового начальства не проглядається: людей змушують утримувати позиції під вогнем арти і РСЗВ, потім, коли вся техніка вже знищена і відбиватися толком нічим, командири на свій страх і ризик приймають рішення про відхід» ${ }^{27}$.

Не залишає поза увагою автор - учасник бойових дій i ворога, систематично використовуючи для його характеристики поняття «сепари/сепаратисти»: «Сепари стріляють 3 дзвіниць, а нашим у відповідь стріляти забороняють ${ }^{28}$. Також описується реакція українських війських на конкретні дії ворога: «Самі сепари займають висоти, терикони, ставлять там міномети і снайперів. Іноді по ж/д дорозі возять платформи 3 мінометами. Якщо почув стукіт коліс, значить, скоро буде обстріл» ${ }^{29}$; «Під час перемир'я стоїш на блокпосту, сидиш: сепари відкрито міни ставлять» ${ }^{30}$.

Автор звертає увагу на те, що війна, участь у бойових діях нівелює цінність життя зокрема і систему цінностей загалом, які працюють у мирному світі, а ворог - категорія, що вимагає спеціального тлумачення, адже він має бути кимось іншим, не людиною, щоб були підстави його вбивати: «Межа між трагедією i фарсом на війні стирається - зрозуміти, з якого дива тобі потрібно стріляти в таких же людей, як і ти, можна тільки за допомогою стрічок $<\ldots>>{ }^{31}$.

\footnotetext{
25 Якорнов Д. То АТО. Дневник добровольца. Харьков : Виват, 2016. С. 125.

${ }^{26}$ Там само. С. 312.

${ }^{27}$ Там само. С. 57.

${ }^{28}$ Там само. C. 23.

${ }^{29}$ Там само. C. 29.

${ }^{30}$ Там само. С. 29.

${ }^{31}$ Там само. С. 239.
} 
Для організації воєнної історії з позиції автора - учасника подій характерно: використання формату щоденникових записів із фіксацією дискретних, неорганізованих у єдине ціле, суб'єктивних відчуттів і оцінок конкретних миттєвостей війни для передачі аудиторії «живого», невідфільтрованого, досвіду війни; демонстрація суб'єктивного образу війни та моделювання воєнних подій як персональної війни.

\section{ВИСНОВКИ}

Для сучасної української воєнної документалістики про події на Сході України 2015-2020 pр., яка здатна не тільки інформувати про перебіг подій, а й формувати/змінювати уявлення про цю війну, впливаючи на громадську думку, характерне репрезентування воєнної історії ззовні і зсередини, - з позицій автора - спостерігача за подіями й автора - учасника подій.

Перший тип репрезентації історій має такі характерні ознаки: передача чужого воєнного досвіду (через інтерв'юванню військовослужбовців); дотримання автором позиції модератора, що контролює та спрямовує перебіг бесіди, щоб розкрити проблему та передати пережитий героями травматичний досвід; забезпечення реалізації Я-наративу через використання прямої мови безпосередніх героїв подій; відсутність оцінок i коментування дій героїв із боку автора; моделювання світу війни через репрезентацію концептів семантичного поля «війна» для створення умов для осмислення феномену війни українським суспільством з урахуванням досвіду учасників бойових дій, проте 3 позицій позазнаходження щодо контексту воєнних подій, відсторонено, але принципово і з опертям на факти.

Другий тип репрезентації воєнної історії (з позиції зсередини) має такі характеристики: сконцентрованість на внутрішньому світі героярозповідача; суб'єктивне та дискретне оцінювання сприйнятого й пережитого конкретним героєм-розповідачем досвіду війни; репрезентація авторських відчуттів і оцінок щодо конкретного моменту перебування на навчаннях/війні, без фільтра часової та/чи просторової дистанції; фрагментарне відтворення історії війни з метою передати миттєвості війни, що значним чином вплинули на емоційний стан героя-розповідача «тут і зараз» та моделювання воєнних подій як персональної війни.

\section{АНОТАЦІЯ}

Сучасна українська документалістика про події на Сході України - це відповідь на запит сучасного українського суспільства, яке потребуєсвідомо чи неусвідомлено - об'ємного, розгорнутого, щирого, точного, правдивого репрезентування нинішнього воєнного досвіду українців 
і України. Кожна книга цієї тематики моделює авторське бачення світу війни та місце людини в цій реальності. Науковий інтерес до такого виду вербальної творчості пояснюється необхідністю дослідження способів моделювання сучасної української історії, у якій наявний воєнний досвід, що дасть можливість з'ясувати, як сучасники війни на Сході України в особі журналістів і учасників бойових дій бачать іï та на що урешті-решт орієнтують суспільну увагу, на чому формується широка громадська думка щодо конфлікту на Сході України.

Способи осмислення сучасного українського досвіду війни в нефікціональних творах - тих, що зорієнтовані на фактичний досвід війни та мають прямий зв'язок із дійсністю, - предмет нашої уваги. Об'єктом дослідження є книги про війну на Сході України - «АД 242. Історія мужності, братерства і самопожертви» (2016 р.) та «То АТО. Щоденник добровольця» (2016 р.). Предмет дослідження - проблемно-тематичні лінії, авторська позиція та стратегії, які використовуються для репрезентації досвіду війни. У процесі роботи були використані загальнонаукові методи дослідження (описовий, аналізу, синтезу, порівняння) та спеціальні (структурний, герменевтичний, наративний, метод контент-аналізу). Насамперед важливо було зрозуміти, у якому контексті та як саме автори вживають слово «війна» (або його синоніми чи альтернативні визначення) стосовно подій на Сході України. Під час дослідження було виявлено особливості сучасної воєнної документалістики, що полягають у зміні формату подачі матеріалу (зокрема, інтерв'ю з військовослужбовцями та використання Я-наративу).

Підтверджено, що автор - спостерігач подій надає слово героям свого твору, тобто нарація організовується як демонстрація спогадів, пережитих ключових моментів воєнного конфлікту, а сам автор не тисне на героїв, не провокує вираження емоцій. Простежено, що автор - учасник подій концентрує увагу на індивідуальному сприйнятті подій, у яких брав участь. Головне в такій книзі - передача дискретних i спонтанних власних відчуттів і емоційних вражень від подій, учасником яких став сам автор-розповідач.

\section{ЛIТЕРАТУРА}

1. АД 242. Історія мужності, братерства та самопожертви / за ред. I. Штогрін. Харків : Клуб сімейного дозвілля, 2016. 352 с.

2. Бахтин М. Автор и герой в эстетической деятельности. Эстетика словесного творчества. Москва : Искусство, 1986. С. 9-191.

3. Іванова О. Наратив як складник бренд-платформи. Діалог : медіастудіï. 2011. Вип. 13. С. 39-46.

4. Іванова О. Сад літератури в журнальній оптиці сучасності. Медіакомунікації з, для і про літературу : монографія. Одеса, 2009. 364 с. 
5. Мак-Квейл Д. Новини як наратив. Теорія масової комунікації. Львів : Літопис, 2010. С. 342-344.

6. Маркова О. Письма с фронта как документ военной эпохи. ИНТЕР. 2016. № 12. С. 54-67. URL: https://cyberleninka.ru/article/ n/pisma-s-fronta-kak-dokument-voennoy-epohi/pdf.

7. Рикёр П. Время и рассказ. Москва : Университетская книга, $1998.313 \mathrm{c}$.

8. Сивакова Н. Функции автора в повествовательной структуре «новой» документальной литературы. Известия Гомельского государственного университета имени Ф. Скорины. 2006. № 1 (34). C. 76-83. URL: http://old.gsu.by/biglib/GSU/Довузовской\%20подготовки/ научные\%20публикации/сивакова\%20н.а/функции\%20автора.pdf.

9. Скоріна Г. Книжкова сотня, або \#книги_про_війну. Життя після ATO. URL: http://life-after-ato.com.ua/post/231.

10. Червінчук А. Автор - учасник подій у сучасній українській воєнній документалістиці (на прикладі серії книг «Звіт за серпень'14, «Іловайський щоденник», «Савур-Могила»). Діалог : медіастудії. 2018. Вип. 24. С. 265-274.

11. Червінчук А. Наративність оповіді матеріалу в українській воєнній документалістиці (на прикладі книги «АД 242. Історія мужності, братерства і самопожертви»). Актуальні проблеми розвитку засобів масової комунікації в сучасній Україні : матеріали V Всеукраїнської науково-практичної конференції для студентів та аспірантів, 21 квітня 2017 р. Вінниця, 2017. С. 46-47.

12. Якорнов Д. То АТО. Дневник добровольца. Харьков : Виват, 2016. $400 \mathrm{c}$.

\section{Information about the authors: Ivanova O. A.,}

Doctor of Social Communications, Professor, Dean of the Faculty of Journalism, Advertising and Publishing Odessa I. I. Mechnikov National University 24/26, Frantszuzkyi bulvar, Odesa, 65068, Ukraine

Chervinchuk A. O., $\mathrm{PhD}$ Student (Social Communications) of the Faculty of Journalism, Advertising and Publishing Odessa I. I. Mechnikov National University 24/26, Frantszuzkyi bulvar, Odesa, 65068, Ukraine 